Session 2131

\title{
A Pilot Investigation of Functional Roles on Engineering Student Teams
}

\author{
Ms. Jeannie Brown Leonard, Dr. Janet A. Schmidt, Ms. Paige E. Smith, \\ \& Dr. Linda C. Schmidt \\ University of Maryland, College Park
}

\section{Introduction}

The project team has become a primary learning environment for engineering students. Engineering education accreditation ${ }^{1}$ has been revised to include the ability to function on multidisciplinary teams as a required student learning outcome in response to industry identification of shortcomings in team skills ${ }^{2}$. Unlike other science, technology, and mathematics disciplines, graduates of engineering programs typically enter a work environment that immediately requires team and interpersonal process skills. From the perspective of education, positive team project experiences can motivate students to perform at higher levels. Well-functioning teams have been shown to improve learning and retention in non-engineering fields, especially for members of underrepresented groups $3,4,5,6,7$.

Previous research suggests that while most engineering faculty are committed to using project teams in their classrooms, they have little or no formal training on how to work with student teams or how to teach team members to work well together ${ }^{8}$. Focused on their discipline and on pedagogy, the majority of engineering instructors do not place a high priority on learning the theory and practice of what makes teams effective learning environments. For the few who do have the motivation to translate psychological and business related research into the context of the engineering student project team, the task is difficult. For example, team functioning has been described with over 130 different labels $^{9,10}$. Compounding the confusion, much of the available research on teamwork was conducted using military teams and contrived experiments where volunteers simulate team situations, making the application to engineering project teams unclear $^{11,12}$. However, despite problems with terminology and disciplinary contexts, one of the most consistent aspects of the literature on teams in a variety of settings is the importance of team roles ${ }^{13,14}$. The importance of team roles is based on the notion that certain predictable processes and behaviors must occur (represented by roles such as Facilitator or Leader) if a team is to be successful. Increasing the awareness of team members to these roles increases the chance that appropriate behaviors will occur and the team will be successful.

To empirically explain and better understand the importance of team roles in engineering project teams, we conducted a qualitative study. A variety of engineering team experiences were investigated ranging from first-year students involved in teams for the first time as part of an Introduction to Engineering Design course (ENES 100) to seniors completing capstone engineering courses. Freshmen teams provided the baseline or "naïve condition" since most of these students had few prior team experiences. Seniors, on the other hand, are individuals who

"Proceedings of the 2004 American Society for Engineering Education Annual Conference \& Exposition Copyright (C) 2004, American Society for Engineering Education" 
have "made it" through the engineering curriculum and have been members of a variety of teams throughout their undergraduate careers. They have mastered engineering content with sufficient proficiency to be a semester or two away from graduation. Because of their background with teams, seniors were expected to represent the "epitome" of undergraduate team members that can be found in the engineering education environment. Our goal was to compare and contrast freshmen and seniors on a variety of issues related to the importance of roles in effective team performance and student mastery of engineering content.

\section{Background on Roles in Teams}

The types of roles individuals play on teams have been described by a number of authors ${ }^{13,14,15}$. For example, Gibbs ${ }^{13}$ team roles include Innovator, Investigator, Chairperson, Shaper, Evaluator, Team Worker, Organizer and Finisher. Rees ${ }^{14}$ identified similar roles (Team Leader, Facilitator and Recorder) as did McGourty ${ }^{15}$ (Active Listener, Fact Seeker, Innovator and Goal Director). While roles such as these speak to the group process part of the ideally functioning team, engineering educators have overlooked another set of important team roles. These are roles related to the accomplishment of the engineering project and require specific skills such as design ("Design Specialist"), construction ability ("Builder"), report writing ("Technical Writer"), or computational expertise ("Number Cruncher"). These roles are distinguishable from the group process roles noted above which directly impact group dynamics and harmony.

Adoption of specific functional roles by students in teams can impact their subject matter mastery. Unlike the team model typically used in the corporate world that stresses timely and cost effective development of outstanding products, the goal of engineering educators is to facilitate the learning of each individual team member. Engineering project teams have the potential to influence the student's satisfaction, sense of competence, and persistence in the field. An "ideal" team experience in engineering education can be defined as having the following characteristics $^{16}$ :

1. Positive team performance in terms of both team processes (e.g., personal and interpersonal interaction) and team outcomes (e.g., the product);

2. Demonstrated student learning of engineering content and skills; and

3. Maintenance or enhancement of student commitment to engineering as a field (e.g., increased self confidence, satisfaction, and desire to persist in the engineering curriculum).

In trying to understand better the role taking behaviors typical on engineering project teams, research findings from the business, human factors, and psychology literatures have proven helpful. Within the team's lifecycle, two work categories have been identified: teamwork and $\operatorname{task}$ work $^{17,18}$. The interaction that occurs between team members refers to teamwork, while the behaviors that occur due to the individual's responsibilities related to the team project refers to task work. The behaviors that are important to effective or ineffective teamwork include adaptability, ability to give and receive suggestions and criticisms, communication, coordination, cooperation, and team spirit. Examples of task work range from designing components to developing technical presentation skills and presenting the team's final report.

Furthermore, researchers found divisionally and functionally based roles are better suited in different work environments. Functionally based roles are those that require specialization: one

"Proceedings of the 2004 American Society for Engineering Education Annual Conference \& Exposition Copyright (C) 2004, American Society for Engineering Education”" 
team member performs one specific function (e.g., a team member acts as the company webmaster). On the other hand, divisionally based roles are broader: requiring the team member to perform all necessary roles for project success, but with in a limited scope (e.g., for a region or company subsection). In relatively predictable and stable environments, functionally based roles tend to be more effective than divisionally based ones. This is because functional roles promote efficiency (everyone is doing a separate and unique task required in project completion). However, in unpredictable or unstable environments, divisionally based roles tend to be more effective because they are flexible and team members possess a broader set of skills. Functionally oriented team members can react more quickly to adapt to the changing environment or situation ${ }^{19}$.

The commonly referred to "trade-off" between effectiveness and efficiency in the business team literature appears to be a little acknowledged problem in engineering project teams that may negatively impact student learning. While specialization promotes efficiency in completing the task, it works against broad mastery of multiple skill sets ${ }^{20}$. In a rare engineering reference to the notion of "functional" roles, Johnson ${ }^{21}$ noted that one way to encourage breadth of learning on teams is to require students to rotate roles (e.g., leader, editor, technical computations, library research and writer). However, when left to choose their own roles on teams, engineering students appear to repeatedly gravitate to the same functional roles, the ones in which they are already skilled. Similar to business and industry, students seem to value getting the job done (efficiency) at the expense of effectiveness. In the context of engineering education, effectiveness is defined as breadth of learning.

Students may be unintentionally reinforced into taking functionally based, efficient task roles by their engineering professors. Because professors usually lay out the project requirements and constraints, as well as timeline for completion, they create a "predictable" environment that favors specialization $^{22}$. Thus engineering educators may be short changing their students by allowing them to become task specialists at the expense of broad learning and preparing them for more predictability than the conditions they will find once they engage in "real world" occupations and projects. As engineering educators, we would like each student to be proficient in all aspects of the subject matter and be prepared to work in the rapidly changing world of engineering and industry. Rather than focusing on a specialized task role in the team such as "Construction Expert," each team member should multi-task, performing all tasks necessary to complete the team project and learn all the engineering content.

\section{Study Method}

Using a qualitative methodology (focus groups), six intact teams from selected courses (e.g., first-year students taking the Introduction to Engineering course (ENES 100) and seniors completing their senior capstone experience) were interviewed. This methodology was chosen because the aim was to solicit a multiplicity of views within a group context.

Unlike interviewing an individual, the aim of the focus group is to capture the group dynamics and group experience about the subject in question. Among the advantages of focus groups are the in depth quality of the information acquired, the relative efficiency of the method, the potential benefit to participants who gain perspective and insight by exploring the subject with

"Proceedings of the 2004 American Society for Engineering Education Annual Conference \& Exposition Copyright (C) 2004, American Society for Engineering Education” 
others, and the flexibility to follow-up on interesting leads or unanticipated material ${ }^{23}$. Like all research methods, focus groups have limitations as well. Among these are the difficulty in assembling the groups, the need for expert moderators or facilitators, lack of control over the interaction, and the potential lack of confidentiality, and anonymity among participants ${ }^{24}$. Focus group participants tend to be more forthcoming when other group members are strangers, ${ }^{25}$ otherwise the responses may be mediated by the social context of the focus group. Conducting focus groups with in-tact teams violates this preference. To account for the possibility that team members would not candidly discuss their team experiences with team members present, all participants completed a brief follow up survey at the end of the focus group discussion. They indicated the extent to which they agreed with the statement, "I did not withhold or edit my comments because my teammates were present." All but three of the 27 respondents indicated they "Agree" or "Strongly Agree" with this statement. One student replied with a "Neutral" response and two others disagreed. Each of three students indicating that they may have modified their comments in the presence of teammates was on a different team.

The types of questions used in focus groups can be described as "open ended probes 23 ". Since the purpose was to elicit information without too many prescriptions, the focus group questions were worded so the question itself did not influence the participant's answer. Questions were developed for the following areas of research interest:

- Introductory Questions

- Overall Team Functioning

- Functional Role Questions

- Process Role Questions

- Content and/or Knowledge Mastery Questions

The focus groups were organized and conducted by the Principal Investigators and graduate research assistant funded under the NSF ASA Proposal Number 0243265 using the tested focus group protocol. A complete protocol is available from the authors. Examples of specific questions related to roles students play on engineering project teams include:

- What functions do you prefer to do when working on a team?

- Are there roles or functions of working on a team that you like to do, but for some reason, seldom get a chance to do? If so, what gets in the way?

- Do you use the team experience as an opportunity to learn new skills? If not, why? If yes, please describe how or give examples.

- In different team settings do you find yourself performing the same tasks over and over? Is this by your choice? The team's choice?

- How are group dynamics and interactions managed in effective teams?

- What are the special group process roles you like to fill on project teams (e.g., leader, facilitator)?

The focus groups were tape-recorded. To protect confidentiality, students selected pseudonyms for the conversations. None of the investigators was in a position of authority over any of the participants in terms of supervision or grading. Care was taken to ensure confidentiality. The recordings were transcribed and a content analysis was conducted related to our key research questions. Preliminary findings for one freshman team focus group and one senior team focus group are described in the next section. 


\section{Roles and Teams: Preliminary Findings}

The content analysis revealed five themes including characteristics of successful teams, role specialization, team process, functional role identification, and team learning. Table 1 contains a summary of these themes for novice engineering students enrolled in the introductory engineering design course (ENES 100) and experienced mechanical engineering students engaged in a capstone course (ENME 472). Defining characteristics for each theme are in bold type in the table followed by evidence from the focus groups to support each characteristic.

Table 1: Emerging Themes on Student Roles on Engineering Project Teams

Theme 1: Characteristics of a successful team

ENES 100: Introduction to Engineering
ENME 472: Mechanical Engineering Capstone Identified interpersonal goals

- "everyone would have to get along with each other"

- "We want to have fun"

\section{Identified project goals}

- "Everyone has to contribute, to know what is going on and help out."

- "Everyone has a vested interest ...because they want to get an A in the class"

- "[A team member] said we should be as efficient as possible and we all just agreed."

- "We are being proactive and looking at what we need to do and taking action when we need to take action...we've been working hard at this and not slacking."

\section{Teams broaden range of expertise}

- "We each know a different area that we can concentrate on. If I was doing it all by myself, I wouldn't know where to start"

Set goals, developed ground rules and group norms

- "Our goal was to....never have to spend all night in the computer lab"

- "Probably one of the first things we just discussed... about no late nights"

- "If you can't be there, you still need to make sure your contribution makes it to the meeting."

- "Make sure your work is there, make sure it's correct, and make sure we don't have to stay up all night long to do it."

- "Everybody here wants to get this project done. We all want to see the real working thing"

- "Everybody here wants an A in the class, everybody here wants to get the project done. Everybody here has at least an interest in this specific project."

- "You've got to know who you're working with and know...their work standards"

- "I take issue with personality. Mindset I would agree with, but I don't think personality shows through...It's how you're looking at doing your work."

- "for me it was trusting other people enough [about prospective team members] knowing that you're of the same mindset to have somebody here that I didn't know."

- "how do they actually function when they need to get work done?"

- "Some of us get on each other's nerves... but we work together very well."

\section{Picked team members based on skills}

- "a little bit was just luck...I know that when we were talking about the groups, it sounds good on paper...I know it ended up working out a lot better than I even thought it could. ...we ended up meshing"

- "the roles fell into place...[because] we found people's strengths and you know how people work." 
Theme 2: Role specialization on teams

\begin{tabular}{|c|c|}
\hline ENES 100 & ENME 472 \\
\hline $\begin{array}{l}\text { Students filled roles related to their } \\
\text { strengths } \\
\text { - "One of our teammates is really good at one aspect } \\
\text { such as programming and another team member was } \\
\text { good at building the weather station." } \\
\text { - "It helps that a lot of our group had prior knowledge } \\
\text { of things going into [the project]...we had someone } \\
\text { who could already program, do the webpage, do the } \\
\text { wiring." } \\
\text { - "I think we are all doing the things we do best, so we } \\
\text { are not really discontent." } \\
\text { - We each know a different area that we can } \\
\text { concentrate on." } \\
\text { Ideas about the best model } \\
\text { - "Each individual part [is] done well with input from } \\
\text { every other person who doesn't have that specialty." } \\
\text { "We each have our own individual thing that we are } \\
\text { good at, like specialty, but each member still works } \\
\text { under the person that's really good at it and...helps } \\
\text { out." } \\
\text { "I think we all do at least a little part of everybody } \\
\text { else's job too." }\end{array}$ & 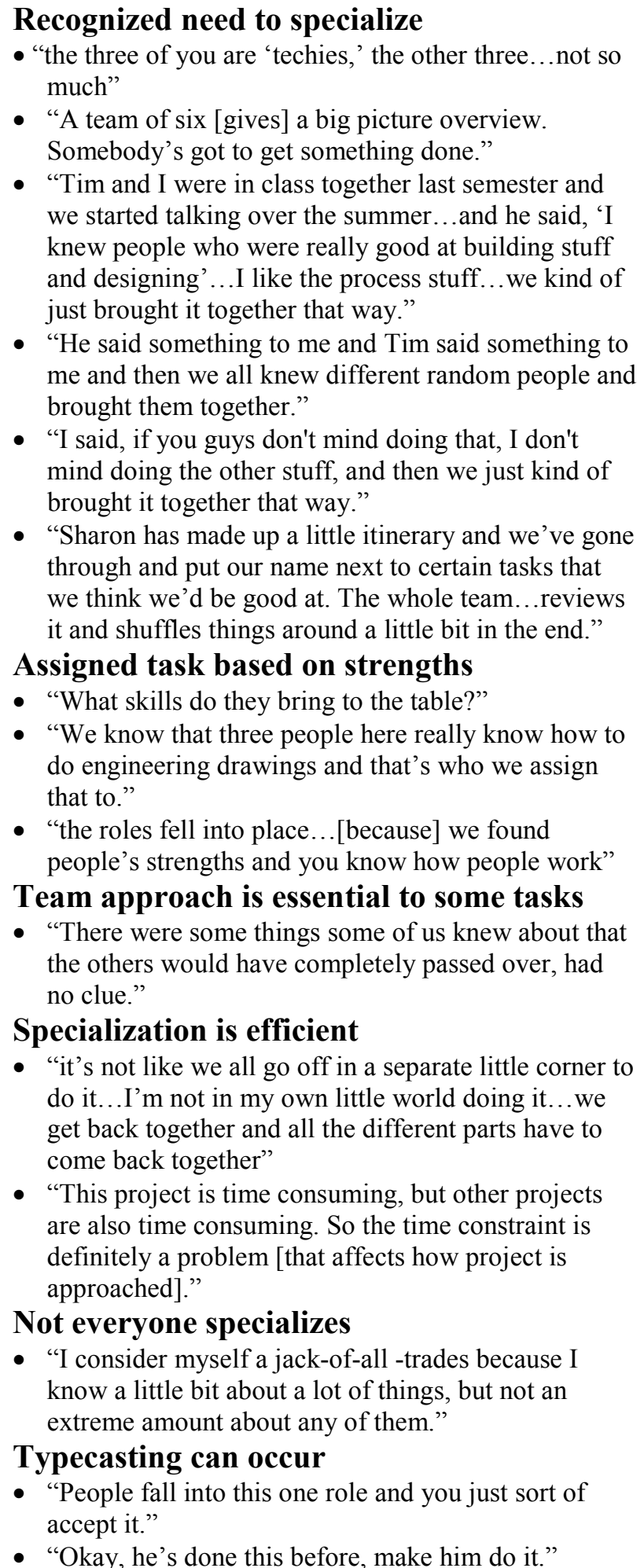 \\
\hline
\end{tabular}

"Proceedings of the 2004 American Society for Engineering Education Annual Conference \& Exposition Copyright (C) 2004, American Society for Engineering Education" 


\begin{tabular}{|c|c|}
\hline ENES 100 & ENME 472 \\
\hline $\begin{array}{l}\text { Prefer to work alone on projects } \\
\text { - "We're the group of people who wanted to work } \\
\text { alone." } \\
\text { - "we all have reasons for not wanting to work in } \\
\text { teams... usually...somebody doesn't care... and they } \\
\text { just wouldn't work and wouldn't help out...they just } \\
\text { really drove the team down" } \\
\text { - "we are a team, but when we're getting stuff done, we } \\
\text { are often working alone...we decide who is going to } \\
\text { what, and then we split up...do what everyone needs } \\
\text { to do and then we come back at the end...work to } \\
\text { synthesize that into our project" } \\
\text { Problem solving } \\
\text { - "We just sit down as a group or with who ever is there } \\
\text { that day and we discuss, here is a problem...we work } \\
\text { out the best solution." } \\
\text { Teamwork cannot be taught } \\
\text { - "Teamwork is something you get, it's not something } \\
\text { that can be taught in lectures...it's an innate sense." } \\
\text { - "A lot of this is very intuitive...we draw from } \\
\text { teamwork experience in other parts of our lives." } \\
\text { Having a leader is important } \\
\text { - "Somebody really has to take charge. There really } \\
\text { does have to be a leader...if you have all six members } \\
\text { trying to make decisions then it will take you forever } \\
\text { to reach any kind of consensus." } \\
\text { - "[The team leader] is a sophomore, he transferred } \\
\text { here. I'd say seniority plays a part. Also he seems to } \\
\text { have some experience" }\end{array}$ & $\begin{array}{l}\text { Took team skills for granted } \\
\text { - "Lucky to be on a good team where personalities } \\
\text { don't interfere with getting the work done" } \\
\text { Work style } \\
\text { - "A major part of the project is defining the problem } \\
\text { and narrowing the problem and then coming up with } \\
\text { a concept and solutions." } \\
\text { - "it's not like we all go off in a separate little corner to } \\
\text { do it...I'm not in my own little world doing it...we } \\
\text { get back together and all the different parts have to } \\
\text { come back together" } \\
\text { Process management } \\
\text { - "[Sharon's] a champ at chasing down paperwork. } \\
\text { She's always got an itinerary of like what we're } \\
\text { supposed to do." } \\
\text { Situational leadership } \\
\text { - "The way that we worked out...it just hasn't really } \\
\text { been necessary [to have a team leader]. Everybody is } \\
\text { responsible." } \\
\text { - "If I had to pick one [a leader], I would definitely say } \\
\text { Sharon." }\end{array}$ \\
\hline
\end{tabular}


Theme 4: Types of learning in project teams

\begin{tabular}{|c|c|}
\hline ENES 100 & ENME 472 \\
\hline $\begin{array}{l}\text { Sought outside resources and relied on prior } \\
\text { knowledge } \\
\text { - "I actually had to go and get [a] physics textbook and } \\
\text { look it all up just to pass my exam." } \\
\text { - "I am kind of taking the initiative and just looked } \\
\text { through the books that we had." } \\
\text { - "Not all professors are going to teach you...perhaps } \\
\text { that is a good life lesson but still got kind of } \\
\text { frustrating for those members of our team who don't } \\
\text { have a good grip." } \\
\text { Shared individual knowledge with others } \\
\text { " "we had a study group the night before [the mid- } \\
\text { term]...we coordinated so we all knew what was going } \\
\text { on with the project" } \\
\text { - "each member still works under the person that's } \\
\text { really good at it and like, helps out" } \\
\text { "I have learned...I watched the building and wiring" } \\
\text { Appreciate how engineers think } \\
\text { - "[Engineers] have a certain aptitude for math and } \\
\text { science in addition to being able to think in a certain } \\
\text { way as opposed to an English or humanities way of } \\
\text { thinking...it is very abstract." }\end{array}$ & $\begin{array}{l}\text { Team discussed technical issues, but } \\
\text { recognized not practical to learn everything } \\
\text { - "Ideally we all discuss things together" } \\
\text { - "making sure it isn't just three people who } \\
\text { understand" } \\
\text { - "it is what they want, but there isn't time for doing it } \\
\text { that way" } \\
\text { - "There were some things that some of us know about } \\
\text { that others would have completely passed over." } \\
\text { Integration of previous knowledge } \\
\text { - "becoming evident that we are going to need a lot of } \\
\text { stuff from other classes" } \\
\text { Strategies for learning } \\
\text { - "I immediately go for people... who have skills in an } \\
\text { area where I know I am weak...you can learn } \\
\text { something from them." } \\
\text { Learned how to pick members for a } \\
\text { successful team } \\
\text { - "Having team members who know certain skills } \\
\text { helps others learn" } \\
\text { - "I didn't ask their GPAs...I have seen what they can } \\
\text { do...we have had direct contact with everybody else } \\
\text { in our group...all have the same mindset" } \\
\text { - "What I know is what I know... what my skill set is } \\
\text { and what I can contribute." }\end{array}$ \\
\hline
\end{tabular}

Theme 5: Functional role identification

The freshman team identified seven functional roles:

- Programmer

- Builder

- Web site developer

- Fabrication/construction head

- Meeting organizer

- Photographer

- Writer

The senior team described six functional roles:

- The techies or gear heads

- Number crunchers

- Project manager

- Integrator/Reviewer

- Researcher

- Writer 


\section{Implications}

The student team in engineering offers a critical and under-studied influence on 1) development of process and functional role skills and 2) student learning or mastery of engineering content. The two teams compared in this analysis represented extreme cases of experience with regard to engineering project teams. Both teams described themselves as well functioning, but their interpretation of this descriptor differed. The freshman team linked the quality of their team to the quality of their product and the absence of overt friction. Early in the semester they intentionally decided to work ahead of schedule and strive for a functioning product while spending as little money on project related expenses as possible. Efficiency was their primary goal. Although the members of this team described themselves as loners, they were pleasantly surprised by how well their group functioned. Their success was largely due to chance and a commitment to some shared goals. This team believed experience was the best way to learn about teamwork, reporting little confidence in formal team training. Despite their surprise and enjoyment of this team experience, no one reacted positively to the notion of future team based engineering classes.

Seniors, on the other hand, attributed their success to the careful selection of team members, a shared mindset, work ethic, and motivation to complete the project to a high quality standard. Although luck may play a role, these students were seasoned members of engineering project teams. They cited their prior team experiences as critical to their understanding of how to make a team operate effectively. For them, efficiency was crucial in juggling many competing academic and personal demands.

Conversations about knowledge and skills individuals contributed to the team project were prominent in both focus groups. Novice engineering students expressed relief that their team happened to include people with the specific talents needed to complete the project. These talents included functional roles that were necessary to complete the content specific activities. These roles are listed in Table 1 under Theme 5 and include programmer, builder, and web site developer. For the most part, these roles were not shared, with the exception of the building function. The group process roles were less understood. There was a clear leader and a person responsible for maintaining a schedule, but other process roles (such as conflict manager, facilitator, etc.) were less evident.

For the seniors, functional skills were a key criterion in deciding who would be on the team. Departmental folklore about the demands of this capstone course prompted some members of this team to begin networking in the semester prior to the course. Over the summer, they began formally recruiting team members. In addition to skill sets, personal traits such as motivation and work style were key to determining who would be asked to join the team. There were three "techies" on the team who were skilled at technical work such as design creation and drawing. Two others were talented researchers, and the final team member was viewed as a "process police," responsible for monitoring deadlines, ensuring communication and overall project management. It is the role of "communicator" that primarily enhanced the team process. The team members viewed this process role as essential and fully contributing to the success of their work, not just the managerial demands. No one was formally labeled the team leader; however, when pressed, all agreed the process-oriented person filled the role of leader.

"Proceedings of the 2004 American Society for Engineering Education Annual Conference \& Exposition Copyright (C) 2004, American Society for Engineering Education” 
Clearly, both teams specialized in their functional roles and assigned roles based on self-reported strengths or, in the case of seniors, strengths from past experience. In the team of first-year students, most roles were isolated, meaning the student fulfilling each function worked independently and shared information with the group only at key points (e.g., in preparation for the mid-term). The building function was one notable exception to the autonomous approach. All team members watched or assisted in building the project. The freshman team focused on creating a functioning project and completing it ahead of schedule. This emphasis on the task relegated learning to the sidelines; learning was incidental for this group. On the other hand, it was gratifying to observe the seniors collaborated more and learned from each other throughout the project. They understood that having multiple perspectives at the brainstorming stage strengthened the initial conceptualization of their project. The complementary skills brought to the project by different members provided an opportunity for learning. They appreciated the importance of learning new skills, but were forced by time constraints to stay within their specialty.

A liability to team process in the freshman team was inconsistent preparation and a lack of shared content background. Under prepared students in this team were diligent in trying to compensate for their weak backgrounds, but relied on books, the instructor, and the Internet more than their team members. In one case, embarrassment prevented a student from asking peers for a chance to build in an effort to develop new skills.

The seniors understood the culminating nature of a capstone course and recognized the project required them to tap skills and knowledge developed in earlier courses. This shared curricular experience facilitated the team process. Inconsistent preparation was acceptable to both teams, but these gaps were less pronounced in senior year compared with freshman year. Seniors specialized, but were aware of and attentive to their teammates' skills. To the degree that time permitted, their approach was more connected and integrated.

The scripted nature of the senior project promoted specialization. Students were dissatisfied with the prescribed project parameters, yet they understood the purpose behind requiring certain benchmarks as indicators of content and process mastery. This team was skilled at learning from their peers. They had a sophisticated sense of how this experience differed from the "real world," but acknowledged the project was preparatory for their entry to actual engineering work.

\section{Conclusion}

These preliminary findings will be augmented by data collected from additional focus groups. Data have been collected from conversations with intact teams at the sophomore, junior, and senior levels as well as with focus groups comprised of all women, all white men, students from underrepresented racial groups in engineering, students who left engineering for other majors, as well as engineers in the workforce. As stated by a senior student, "this kind of course[is] trying to get you to see all aspects... from concept to design to implementation and manufacturing...I think a grade in this course, to me, is more reflective of how you are as an engineer than a lot of the other courses that you take." Comprehensive project based courses are more predictive of who will be a successful practicing engineer than courses on theory. The learning potential of

"Proceedings of the 2004 American Society for Engineering Education Annual Conference \& Exposition Copyright (C) 2004, American Society for Engineering Education”" 
team projects is great. In the voice of a senior student, "I think every group that I've been on has taught me something very valuable."

Once all focus groups are analyzed, more confidence can be placed on the preliminary findings presented in this paper. While all students stand to benefit from improved engineering project teams, enhancing the team experience is likely to have particular significance to women and minorities, both of whom are often isolated or marginalized in the team context. The ultimate goal of this project is to establish the robustness of the construct of functional roles in engineering and to understand better the largely unconscious trade-off engineering educators make between team efficiency and effective team learning.

References

1. ABET Engineering Criteria 2000. (1997). http:/www.abet.ba.md.us/EAC/eac2000.html.

2. Society of Manufacturing Engineers. (1997). "Industry identifies competency gaps among newly hired engineering graduates,” Manufacturing Education Plan: Phase I Report.

3. Barra, R. (1993). Tips and techniques for team effectiveness. New Oxford, PA: Barra International.

4. Smith, K.A., \& Waller, A.A. (1997). “Cooperative learning for new college teachers.” In W.E. Campbell \& K.A. Smith (Eds.) New paradigms for college teaching (pp. 185-309). Edina, MN: International Book Company.

5. Belenky, M.F., Clenchy, G.M., Goldberger, N.R., \& Tarule, J.M. (1986). Women's ways of knowing: The development of self, voice and mind. New York: Basic Books.

6. Wankat, P.C., \& Oreovicz, F.S. (1993). Teaching engineering. New York: McGraw-Hill.

7. Fullilove, R., \& Treisman, P.U. (1990). "Mathematics achievement among African American undergraduates at the University of California Berkeley: An evaluation of the math workshop program," Journal of Negro Education, 59(3): 463.

8. Mead, P.F., Moore, D., Natishan, M., Schmidt, L., Brown, S., Latham, C., \& Mouring, S. (1999). "Faculty and student views on engineering student team effectiveness," Journal of Women and Minorities in Science and Engineering, 5, 351-363.

9. Salas, E., \& Cannon-Bowers, J. (2000). “Teams in organizations.” In. M.M. Beyerlein (Ed.), Work teams: Past, present, and future. Dordrech: Kluwer Academic Publishers.

10. Devine. D.J., Clayton, L.D., Philips, J.L., Dunford, B.B., \& Melner, S.B. (1996). “Teams in organizations: Prevalence, characteristics, and effectiveness." Small Group Research, 30, 678-711.

11. Smith, P. (2003). An analysis of team design and project management support during a design project's lifecycle. Unpublished doctoral dissertation.

12. Ilgen, D.R. (1986). "Laboratory research: A question of when, not if." In E.A. Locke (Ed.), Generalizing from lab to field settings (pp. 257-267). Lexington, MA: Heath.

13. Gibbs, G. (1993). Learning in teams: A student guide. Oxford, England: Oxford Brooks University Press.

14. Rees, F. (1997). Teamwork from start to finish. San Francisco: Jossey-Bass.

"Proceedings of the 2004 American Society for Engineering Education Annual Conference \& Exposition Copyright (C) 2004, American Society for Engineering Education" 
15. McGourty, J., \& De Meuse, K. (2000). The team developer: An assessment and skill building program, John Wiley and Sons Press.

16. Brannick, M.T., Roach, R.M., \& Salas, E. (1993). Understanding team performance: A multi-method study. Human Performance, 6(4), 287-308.

17. Morgan, Jr., B.B., Glickman, A.S., Woodard, E.A., Blaiwes, A., \& Salas, E. (1986). Measurement of team behaviors in a navy environment (NTSC-TR-86-014). Orlando, FL: Naval Training Systems Center.

18. Baker, D.P., \& Salas, E. (1992). "Principles for measuring teamwork skills," Human Factors, 34(4), 469-475.

19. Burns, T., \& Stalker, G. (1961). The management of innovation. London: Tavistock Publications.

20. Heany, D.F. (1989). Deriving performance measures for team tasks: Evaluating a methodology. In Proceedings of the Human Factors Society $33^{\text {rd }}$ Annual Meeting (pp. 1273-1277). Santa Monica, CA: Human Factors Society.

21. Johnson, P (1999). "Problem-based, cooperative learning in the engineering classroom," Journal of Professional Issues in Engineering Education and Practice, January.

22. Hackman, J.R., \& Oldham, G. (1976). "Motivation through the design of work: Test of a theory," Organizational Behavior and Human Performance, 16, 250-279.

23. Gibbs, A. (1997). "Focus Groups," Social Research Update, 19, Conducted for the Department of Social Medicine at Briston University.

24. ASA Series (1997). What is a survey? Produced by Section on Survey Research Methods, American Statistical Association.

25. Vaughn, S., Schumm, J.S., and Sinagub, J. (1996). Focus group interviews in education and psychology. Thousand Oaks, CA: Sage.

JEANNIE BROWN LEONARD, M.Ed., is the Graduate Research Assistant for the ASA project. She oversees the data collection and analysis including scheduling and conducting focus groups as well as editing and coding transcripts. Her primary research interest is student intellectual development and integrative learning. Ms. Brown Leonard is currently pursuing a Ph.D. in Counseling and Personnel Services at the University of Maryland.

JANET A. SCHMIDT, Ph.D. Dr. Schmidt is the co-PI of the NSF sponsored ASA grant. A licensed psychologist, she is the Director for Interidisciplinary Research in the College of Education at the University of Maryland. Her other interests include teamwork training for faculty and students in engineering and assessment activities related to ABET accreditation.

PAIGE E. SMITH, M.S., is Director of the Women in Engineering Program at the University of Maryland and co-PI of the ASA grant. She provides leadership in recruiting and retaining female engineering students for the college. Her current research focuses on engineering design teams and project management. Ms. Smith is a doctoral candidate in Industrial and Systems Engineering at Virginia Tech.

LINDA C. SCHMIDT, Ph.D., Associate Professor, Mechanical Engineering, Clark School of Engineering, University of Maryland. Dr. Schmidt is the PI of the ASA project. In addition to the current project, she actively supports women and minorities in engineering, provides team training for engineering students and faculty, studies engineering design processes, and advises the local chapter of Phi Tau Sigma.

"Proceedings of the 2004 American Society for Engineering Education Annual Conference \& Exposition Copyright (C) 2004, American Society for Engineering Education” 